\title{
The Orthoptera of Madeira.
}

By MALCOLM BURR, D.Sc., F.Z.S., F.L.S., F.E.S., F.G.S.

The Natural History of Madeira has heen well studied by various competent investigators, but, for some reason, the Orthoptera have been strangely neglected. This is probably due to the fact that this order is rather meagrely represented in the island, so that no specialist has thought it worth while to go there, but all the same, it is by no means lacking in special features, as the following notes will show. These are based on the results of a week's collecting in the island at the end of September last, supplemented by some material in the Museum of the Seminario.

This Museum should be visited by all travellers who are interested in Natural History. Its creation is a monument to the energy and enthusiasm of one man, Padre Ernesto Schmitz, who made Madeira his home for thirty strenuous years, in which he amassed rich and thoroughly representative collections in all branches of Natural History. Unfortunately for Madeira, Padre Schmitz has been translated about two years ago to Jerusalem, but on his departure he bequeathed his task to an ardent disciple, Padre Jayme de Gouvêa Barreto, a Madeiran born and bred, who has thrown himself with enthusiasm into the task of investigating and making thorough collections of the Fauna and Flora of the Archipelago.

Before leaving Madeira, Padre Schmitz had the pleasure of seeing his collections well housed in a large room in the Seminario, an ecclesiastical educational establishment of which he was Prior, where the Museum is well-fitted and housed, at the cost of the institution, supplemented by occasional contributions from visitors.

The insects are not so well represented, for Padre Barreto is single-handed, and in addition to his normal duties in the Seminario, mounts and preserves all specimens himself, including the birds ard fish, as well as collecting in every branch of Natural History. His task has been made even harder since the Portugese Revolution, which incidentally I witnessed, calling in Lisbon two days after leaving: Madeira, for the Republican authorities, in their anti-ecclesiastical zeal, removed Father Barreto's colleagues from the educational section of the Seminario, leaving him alone to do all the good work, so that he has since had little time or energy for science. Not being a lepidopterist, I am unable to say much of the butterflies, but a case in the Museum contained Danais archippus, the beautiful Diadema inaria, Goneptery $x$ cleopatra, Colias edusa, with the var. helice, Colias hyale, Aryynnis lathrmia and Fyrameis atalanta. The collection of Coleoptera is a good one, as there is an abundance of peculiar local forms, and the order has been well worked.

The spiders too have been well studied, and there is a fairly full collection, all determined and worked out.

The Herniptera have not yet received attention, nor the Hymenoptera, nor the Myriapods, and Father Barreto is anxious to enter into correspondence with specialists who will work out material in the two latter groups.

Madeira rejoices in three peculiar species of earwigs. These are, Perirrhytus edentula, Wollaston, which seems to be rare, as I failed

February 15th, 1912. 
to find it in spite of careful search ; there is the allied P. madeirensis, Borelli, discovered by Padre Schmitz, in similar localities with $P$. edentula, under stones, on the lower levels; finally there is $P$. schmitzii, Borelli, discovered by Padre Barreto near Poizo, at a considerable elevation. All these earwigs have been taken by hazard only, and though I spent very many hours industriously turning over stones in various localities, I failed to come across any of them. Indeed, of the two latter species, the three or four original specimens are the only ones known to exist in collections. Forficula auricularia, L., is fairly common, but far less abundant than in Europe. I found a single male lying dead on the path near the Grand Corral. There are several specimens including var. forcipata, Steph., in the Museum. Labidura riparia occurs on the coast, there are a few specimens in the Museum, and I possess some taken at Funchal in 1884. The common earwig of the island is Anisolabis annulipes, Luc., which Father Barreto and I found in numbers under stones in a dry river bed just outside Funchal ; this was on September 30th, and they generally occurred in pairs, the female, in three instances, sitting in an apparently dug-out depression in the earth, taking care of a pile of about a dozen minute oval cream-coloured eggs, a little less than $1 \mathrm{~mm}$. in length.

In the Königsberg Museum. there are specimens of $F$. auricularia, L. riparia and Labia minor; the last species I did not come across. Padre Barreto has found that Labia curvicauda, Motsch, occurs in numbers in the Seminario in Funchal. This little species is probably of Oriental origin, but now occurs in all tropical countries.

On one occasion I came across a little procession of Termes lucifugus, Rossi, under the same stone.

Various foreign cockroaches find the climate congenial, and Rhyparobia maderae, Fabr., is apparently long since established, but it is highly improbable that it is indigenous in spite of its name, for the fauna is essentially palæarctic, and the Panchloridae are a neotropical group; R. maderae is now cosmopolitan.

There are two indigenous Blattids known: Loboptera decipiens, Germar, is common, but I only saw a single adult specimen, though nymphs, larvæ and oothecae were abundant under stones in all localities. The other species is Hololampra infumata, Br., which is rarer. Padre Barreto lent me the three or four specimens to submit to Mr. Shelford for determination. He has taken it at Poizo, on the mountain. It remotely resembles Ectobius panzeri, and was recorded as that species by Wollaston, under the name of E. ericetor um (Woll. Ann. Mag. N.H., 1858, p. 21). He found it in pine woods from 4,500 to $5000 \mathrm{ft}$. above the sea. It is allied to the South European A. marginata, Schreb.

Mantis religiosa, L., occurs; I did not see a living one, but there are two or three in the Museum. Padre Barreto looks upon it as a rarity.

In the Acridiodea I found three females of Chorthippus pulvinatus, Fisch. de W., on the steep mountain slopes, above the pines, in the Grand Corral ; all three specimens had the elytra and wings strongly abbreviated; the length of these organs is extremely unstable in this species, but as a general rule, they are longer in the more southern area of its distribution. Epacromia strepens, Fabr., is common in the 
same locality. Epacromia thalassina, Latr., is the common grasshopper of the island. It swarms everywhere. I found it in all stages of growth in the grass borders in the Botanic Gardens, and every ribeira, or dry torrent, swarms with it, for there are no other uncultivated spots in the lower levels, all the hillsides being given over to vineyards, sugar-cane, and banana plantations. Starronotus maroccanus, Thunb., is recorded from the island by Kirby, but I do not know his authority.

The Oedipodidae are represented by Pachytylus danicus, L., which is common everywhere, by Oelaleus nigrofasciatus, De Geer, which occurs sparingly in the lower levels, but in great numbers in the mountains. I did not come across Sphingonotus caerulans, L., but there are specimens in the Museum; it is recorded from the island by Brunner. Serville describes a species which evidently resembles Acrotylus insubricus, Scop.; he names it Oedipoda maderae (Orth. p. 730, 1839), which de Saussure sinks as a queried synonym of Thalpomena algeriana, and for this reason, Kirby records it under the name of Thalpomena maderae. Probably it is Acrotylus insubricus, as this is a common South European species, which extends as far as the Canaries, and there is no improbability in its occurring in Madeira, though I failed to find it.

The Acriliidae are represented by Caloptenus italicus, L., which is common. The Madeiran race differs somewhat from the continental form in the rather deeper crimson wings. Once at least Schistocerca peregrina, Oliv., has struggled over from Africa. No other Acridian Orthoptera have been as yet noted.

In the Locustine groups, Phaneroptera nana, Charp., is very common in the ornamental shrubs in the hotel gardens; it hides during the daytime, but at night-fall, its presence is betrayed by an intangible tss tss among the branches, very difficult to locate. Conncephalus nitidulus, Scop., is not rare in some ribeiras. Decticus albifions, Fabr., is said by Padre Barreto to be common, but I did not chance to come across it. It is also recorded by Kirby. Platycleis grisea, Fabr., occurs also, but is not common; I took it sparingly in the higher slopes of the Grand Corral. It is also recorded by Kirby. Platycleis barretii, Burr, is a new species, described below, of which I took one pair on the grassy slopes at an elevation of at least $5,000 \mathrm{ft}$. ; it is related to $P$. grisea, but its shortened wings and elytra give it a superficial resemblance to Olynthoscelis griseoaptera, De Geer.

In the crickets Bolivar records Gryllus hispanicus, and Liogryllus bimaculatus is represented in the collection, and I found several immature specimens, but did not come across an adult. After dusk the chirp of the crickets may be heard, but not so intense as in the Canaries or on the mainland. Perhaps L. campestris occurs too, but I saw none of its iridescent larvæ; and I cannot distinguish its stridulation from that of its more southern congener.

Platycleis Barretir, sp.n.- Statura modica; griseo-testacea; elytra fortiter abbreviata, grisea, obtusa; pronotum depressum, lobis deflexis, margine postico et infero albo-marginatis; cerci $\delta$ prope apicem dentati; ovipositor vix incurvus, pronoto duplo longior.

Lon

$\begin{array}{cl}\text { Long. } & \text { corporis } \\ \text {,. } & \text { pronoti } \ldots \\ \text { ", } & \text { elytrorum } \\ \text { " } & \text { femor. post. } \\ \text {, } & \text { ovipositoris }\end{array}$

\begin{tabular}{rrrr} 
& \multicolumn{1}{c}{} & & \multicolumn{1}{c}{} \\
$\ldots$ & $15 \mathrm{~mm}$. & $\ldots$ & $16 \mathrm{~mm}$. \\
$\ldots$ & $5 \mathrm{~mm}$. & $\ldots$ & $5 \mathrm{~mm}$. \\
$\ldots$ & $4.5 \mathrm{~mm}$. & $\ldots$ & $4 \mathrm{~mm}$. \\
$\ldots$ & $15 \mathrm{~mm}$. & $\ldots$ & $16 \mathrm{~mm}$. \\
$\ldots$ & - & $\ldots$ & $11 \mathrm{~mm}$.
\end{tabular}


Size medium; colour greyish and brown, mottled: Antennæ very long. Frons and occiput heavily marbled with brown and cream; the latter with a median pale line; eyes of the same colour. Pronotum depressed, the disc similarly marbled, with a pale median line; median keel prominent in posterior portion; lateral flaps dark brown, with a broad cream margin posteriorly and anteriorly. Prosternum unarmed. Legs grey-brown, mottled and marbled with darker; posterior femora with longitudinal black band on the outer face. Elytra abbreviated, reaching the sixth abdominal segment in the $c$, the fifth in the female, apically rounded, grey-brown, the veins darker and prominent. Abdomen dull reddish-brown. Anal segment in the $\delta$ deeply roundly excavate, with short, rounded lobes. Cerci $\delta$ surpassing subgenital lamina, cylindrical, with a small tooth near the apex; subgenital lamina of tricarinate, with a small round apical emargination, with rounded lobes and short styles. Anal segment $q$ incised; cerci $q$ shorter than in $\delta$, not toothed; subgenital lamina not keeled nor sulcate, with a rounded emargination and rounded lobes. Ovipositor very gently curved, more than twice as long as the pronotum.

Maderra.-Grand Corral, October 2nd, 1910, 1 ð, 1 $q$, (in c.m.).

This is a very distinct species; its nearest relatives are perhaps P. modesta, Fieb. (S. E. Europe), P. saussureana, Frey-Gessner (C. Europe), P. brachyptera, L. (C. Europe), and P. fusca, Br. (Greece). The ovipositor is longer and straighter than in any of these except the last. The cerci of the male are shorter and the tooth much smaller than in P. saussureana, P. brachyptera and P. modesta, and the lobes of the supra-anal plate are short and rounded, not acute.

The subgenital lamina of the female is not sulcate, though the lobes and emargination are rounded. This suggests relationship to the fully winged group of $P$. grisea, Fabr., and its allies. The long ovipositor at once removes it from the group of $P$. tessellata, Charp.

It is probably restricted to the higher parts of the island of Madeira. My attention was attracted by the stridulation, on the steep, grassy and rocky slopes near the Grand Corral, on leaving the tree zone. I only observed it in one restricted locality, and though I saw several specimens I was only able to catch a pair.

It is dedicated, with real pleasure, to Father Jayme de Gouvêa Barreto, the genial Curator of the most interesting Museum, founded by Father Schmitz, in the Seminario in Funchal.

It is the only known saltatorial Orthopteron peculiar to the island.

List of Orthoptera known from Madeira.

Dermaptera.-Labidura riparia, Pall.; Anisolabis annulipes, Luc.; Labia minor, L.; L. curricauda, Motsch.; Perirrhytus edentulus, Woll.; P. madeirensis, Bor.; Pseudochelidura schmitzii, Bor.; Forficula auricularia, L.

Blattodea.-Hololampra infumata, Br.; Loboptera decipiens, Germ.; Rhyparobia maderae, Fabr.

Mantodea.-Mantis religiosa, L.

Acridiodea.-Chorthippus pulvinatus, F. de W.; Epacromia strepens, Fabr.; E. thalassina, Latr.; Stauronotus maroccanus, Thunb.; Pachytylus danicus, L.; Oedalens nigrofasiatus, De Geer.; Sphingonotus caerulans, L.; ? Thalpomena maderae, Serv.; Caloptenus italicus, L.; Schistocerca peregrina, Oliv. 
Locustodea.-Phaneroptera nana, Charp.; Conocephalus nitidulus, Scop.; Platycleis grisea, Fabr.; P. barretii, Burr.; Decticus alhifrons, Fabr. Geer.

Gryllodea.-Gryllus hispanicus, Bol.; Liogryllus bimaculatus, De

Explanation of Plate I.

Fig. 1.-Hololampra infumata, Br., $\subsetneq$.

2.-Platycleis barretii, Burr., $\delta$.

3. id. $\quad$ \&.

4. id. subgenital lamina, $\subsetneq$.

5. id. subgenital lamina, $\delta$.

6. id. supra-anal plate, + .

7. id. supra-anal plate and cerci, $\delta$.

\section{Occasional Notes on the genus Eupithecia in Co. Fermanagh.}

By J. E. R. ALLEN, M.A.

I call this paper "Occasional Notes" because, from many causes, my observations have been far from exhaustive. In particular, my absence from this locality every year during August and a great part of September may have caused me to miss some species.

Eupithecia pulchellata.-Occurs sparingly as an imago. I have not worked for the larva.

E. oblongata.-One specimen only, bred in 1911 from a larva on Senecio jacobaea.

E. scabiosata.-Both larvæ and imagines, but in small numbers.

E. plumbeolata.-Not common.

E. pygmaeata.--One in 1907 and about balf-a-dozen in 1911.

E. satyrata.-Abundant on bogs and mountains.

E. castigata.-Seems to be rather searce, though I have taken both larva and imago. 1910.

E. trisignaria.-About 40 larvæ on Angelica sylvestris in September,

E. virgaureata.-Very abundant. In May the first brood is to be taken at dusk or beaten from hedges. The larvæ are to be beaten from the flowering branches of hawthorn in June and July. The imago occurs again in July and August, and the larva again in the autumn on Senecio jacobaea, S. palustris, Angelica sylvestris, Solidago virgaurea, and probably other plants. I have taken it in the garden, once on a rosebud, and once on a cultivated form of daisy. In September, 1910, the larvæ were very abundant. I took hundreds on ragwort, but a very large proportion of these were stung. Golden-rod is not plentiful here, and I only worked it in one locality, the shore of an island in Lower Lough Erne. The larvæ taken there were much less infested than the larvæ from ragwort, and produced much larger moths. Of the larvæ taken in June and July, some come out as a second brood in July and August of the same summer, some appear with the first brood in the following summer, and I bred one on April 24th, 1909, which had lain two winters in the pupa, from June or July, 1907. I am unable to say whether the autumn larvæ ever lie over for more than one winter. The list of food-plants given above is certainly incomplete. For instance, the progeny of the golden-rod feeding larvæ must find some other food than hawthorn, for there is very little of it growing on the island, where they occur. Similarly 


\section{$2 \mathrm{BHL}$ Biodiversity Heritage Library}

Burr, Malcolm. 1912. "The Orthoptera of Madiera." The entomologist's record and journal of variation 24, 29-33. https://doi.org/10.5962/bhl.part.23221.

View This Item Online: $\underline{\text { https://www.biodiversitylibrary.org/item/38235 }}$

DOI: https://doi.org/10.5962/bhl.part.23221

Permalink: https://www.biodiversitylibrary.org/partpdf/23221

\section{Holding Institution}

Smithsonian Libraries

\section{Sponsored by}

Smithsonian

\section{Copyright \& Reuse}

Copyright Status: NOT_IN_COPYRIGHT

This document was created from content at the Biodiversity Heritage Library, the world's largest open access digital library for biodiversity literature and archives. Visit BHL at https://www.biodiversitylibrary.org. 